\title{
Photosynthetic performance of Salvinia natans exposed to chromium and zinc rich wastewater
}

\author{
Bhupinder Dhir*, P. Sharmila and P. Pardha Saradhi \\ Department of Environmental Biology, University of Delhi, Delhi 110007, India. *Corresponding author: \\ bhupdhir@yahoo.co.in; Tel.: +91-11-27662387; Fax: +91-11-27662387
}

Received: 11 February 2008; Returned for revision: 03 April 2008; Accepted: 22 April 2008

Investigations were carried out to evaluate alterations in photosynthetic performance of Salvinia natans (L.) exposed to chromium $(\mathrm{Cr})$ and zinc $(\mathrm{Zn})$ rich wastewater. Accumulation of high levels of $\mathrm{Cr}$ and $\mathrm{Zn}$ in plants affected photosynthetic electron transport. Photosystem- (PS) II-mediated electron transport was enhanced in plants exposed to Cr rich wastewater while a decline was observed in Zn-exposed plants. Photosystem-I-mediated electron transport increased in plants exposed to $\mathrm{Cr}$ and $\mathrm{Zn}$ rich wastewater. Efficiency of photosystem II $\left(\mathrm{F}_{\mathrm{v}} / \mathrm{F}_{\mathrm{m}}\right)$ measured by fluorescence did not show any significant change in $\mathrm{Cr}$-exposed plants but a decrease was observed in $\mathrm{Zn}$-exposed plants as compared to the control. The enhancement in PS I-induced cyclic electron transport in $\mathrm{Cr}$ and $\mathrm{Zn}$ exposed plants led to a build up of the transthylakoidal proton gradient $(\Delta \mathrm{pH})$ which subsequently helped in maintaining the photophosphorylation potential to meet the additional requirement of ATP under stress. The carbon assimilation potential was adversely affected as evident from the decrease in Rubisco (EC 4.1.1.39) activity. The alterations in photosynthetic electron transport affected stromal redox status and induced variations in the level of stromal components such as pyridine nucleotides in plants exposed to $\mathrm{Cr}$ and $\mathrm{Zn}$ rich wastewater. The present investigations revealed that alteration in the photosynthetic efficiency of Salvinia exposed to $\mathrm{Cr}$ could primarily be the result of a decline in carbon assimilation efficiency relative to light-mediated photosynthetic electron transport, though in the case of $\mathrm{Zn}$-exposed plants both these factors were affected equally.

Key words: carbon assimilation, electron transport, heavy metals, photophosphorylation, redox status

Desempenho fotossintético de plantas de Salvinia natans expostas a água de esgoto rica em cromo e zinco: Avaliou-se o desempenho fotossintético de plantas de Salvinia natans L. expostas a água de esgoto rica em cromo (Cr) e zinco (Zn). O acúmulo de $\mathrm{Cr}$ e $\mathrm{Zn}$ em altos níveis afetou o transporte fotossintético de elétrons. O transporte de elétrons mediado pelo fotossistema (FS) II aumentou nas plantas expostas ao esgoto rico em Cr, observando-se o oposto nas plantas expostas ao esgoto rico em $\mathrm{Zn}$. O transporte de elétrons mediado pelo FS I aumentou nas plantas expostas ao esgoto rico tanto em $\mathrm{Cr}$ como em $\mathrm{Zn}$. A eficiência do FS II $\left(\mathrm{F}_{\mathrm{v}} / \mathrm{F}_{\mathrm{m}}\right)$ avaliada por fluorescência não variou significativamente em resposta ao $\mathrm{Cr}$, porém reduziu-se nas plantas expostas ao esgoto rico em $\mathrm{Zn}$, em comparação com as plantas-controle. $\mathrm{O}$ aumento do transporte cíclico de elétrons associado ao FS I acarretou em aumento do gradiente transtilacoidal de prótons $(\Delta \mathrm{pH})$ que, por seu turno, esteve associado com o potencial de fotofosforilação para suportar as necessidades adicionais de ATP sob condições de estresse. O potencial de assimilação do carbono foi decrescido, conforme se deduz da menor atividade da Rubisco (EC 4.1.1.39). As alterações no transporte fotossintético de elétrons afetaram o status redox do estroma e acarretou variações nos níveis de componentes estromais, como nucleotídeos de piridina, nas plantas expostas ao esgoto rico em Cr e Zn. Nas plantas de Salvinia expostas ao Cr, as alterações no desempenho fotossintético foram primariamente resultantes de um declínio da eficiência de assimilação do carbono, enquanto nas plantas expostas ao esgoto rico em Zn tanto a eficiência de assimilação do carbono como o transporte de elétrons comprometeram igualmente o desempenho fotossintético.

Palavras-chave: assimilação do carbono, fotofosforilação, metais pesados, status redox, transporte de elétrons 


\section{INTRODUCTION}

Heavy metals released during industrial activity form a major portion of the contaminants that accumulate in water bodies. Chromium in particular, being highly soluble and bioavailable, exerts toxic effects on biological systems arising from the possibility of free-diffusion across the cell membrane and its strong oxidative potential (Shanker et al., 2005) whereas Zn-induced damage to living systems mainly includes impairment in functioning of several essential enzymes involved in metabolism (Rout and Das, 2003).

Heavy metal exposure induces alterations in the basic metabolic events in plants. Photosynthesis is one of the major physiological processes known to be affected severely by heavy metal stress. The heavy metal-induced damage to the photosynthetic apparatus includes changes in photosynthetic electron transport and carbon fixation capacity (Clijsters and Van Assche, 1985; Krupa and Baszynski, 1995; Siedlecka et al., 1997; Sersen et al., 1998; Shanker et al., 2005). The changes in photosynthetic potential are regulated by enzymes of the ferredoxinthioredoxin system which account for the stromal redox status of the plant (Scheibe et al., 2005; Schrader et al., 2007). Photophosphorylation which is energetically coupled to the flow of protons through ATPase and driven by the transthylakoidal proton gradient also seems to be affected by heavy metal exposure (Panda and Choudhury, 2005; Sharma and Dubey, 2005).

Aquatic plants possess an immense potential to remove heavy metals from wastewater (Dushenkov et al., 1995; Kara, 2005). Though extensive literature is available highlighting the potential of several Salvinia species for accumulation/removal of various heavy metals including $\mathrm{Ni}, \mathrm{Cu}, \mathrm{As}, \mathrm{Pb}, \mathrm{Cr}, \mathrm{Zn}$ from wastewaters (Sen and Mondal, 1990; Sen and Bhattacharya, 1994; Nigam et al., 1998; Nichols et al., 2000; Hoffman et al., 2004; Hadad et al., 2007), the physiological factors and regulatory mechanisms related to the greater potential of plants for tolerating high levels of heavy metals are not known. Moreover, the exact mechanism of damage to the photosynthetic apparatus whether electron transport or carbon assimilation when Salvinia natans is exposed to heavy metals has not been studied. The present studies were carried out to assess the potential of $S$. natans for heavy metal uptake and evaluate the alteration in photosynthetic performance of plants on exposure to $\mathrm{Cr}$ and $\mathrm{Zn}$ rich wastewaters. Detailed investigations were carried out with the aim of assessing the impact of $\mathrm{Cr}$ and $\mathrm{Zn}$ rich wastewaters on (i) photosynthetic electron transport in $S$. natans using polarographic and fluorescence techniques; (ii) carbon assimilation potential through changes in ribulose-1,5-carboxylase/ oxygenase (Rubisco) activity; (iii) photophosphorylation potential; and (iv) stromal redox status.

\section{MATERIAL AND METHODS}

Plant material and growth conditions: Salvinia natans L. (Salviniaceae), a free-floating aquatic fern was chosen as the study material. Plants collected from unpolluted water bodies were maintained in cemented pots $(\sim 1 \mathrm{~m}$ diameter) under natural light conditions. The temperature ranged from 30 to $32^{\circ} \mathrm{C}$. The wastewater samples collected from a $\mathrm{Cr}$ and $\mathrm{Zn}$ plating (electroplating) unit were used as the experimental solution. The wastewater samples possessed $\mathrm{Cr}$ (total) and $\mathrm{Zn}$ at a concentration of $50 \mathrm{mg} \mathrm{L}^{-1}$ and $35 \mathrm{mg} \mathrm{L}^{-1}$, respectively. Tap water was used as control. The wastewater samples were also checked for the presence of other heavy metals. The physicochemical characterization of wastewater was carried out following the standard protocols given in APHA (1998). The parameters such as chloride, total hardness, ammonium nitrogen, sulphate, and phosphate were measured following protocols as detailed in APHA (1998). Electrical conductivity (EC) and total dissolved solutes (TDS) were measured using a conductivity meter (Model 1601 E, Electronic, India). Ten plants of Salvinia were floated in tub containing $1 \mathrm{~L}$ of $\mathrm{Zn}$ rich wastewater. A similar set up was used for the control (tap water) and $\mathrm{Cr}$ rich wastewater. The plants were exposed to metal for $48 \mathrm{~h}$ and subsequently harvested for metal analysis. The physiological and biochemical studies were also carried out after 48 h of metal exposure.

Heavy metal analysis: After harvest, the plant samples were digested using a mixture of nitric and perchloric acid (3:1) (Rai et al., 2003) and analyzed for heavy metal content using an atomic absorption spectrophotometer (AA-6300, Shimadzu Corporation, Kyoto, Japan). Water samples collected at different time intervals were also analyzed for heavy metal content. 
Photosynthetic pigments: The photosynthetic pigments, namely chlorophyll a, chlorophyll $\mathrm{b}$ and total chlorophyll, were estimated according to Arnon (1949). The leaves were homogenized in $80 \%$ acetone and the homogenate centrifuged at $10,000 g_{n}$ for $10 \mathrm{~min}$. The optical density of the supernatant was measured spectrophotometrically at $645,663,750 \mathrm{~nm}$.

Photochemical activities: PSI- and PSII-mediated electron transport was measured in isolated thylakoids using an oxygen electrode (Oxygen Electrode, Hansatech Instruments, Norfolk, England). The thylakoids were isolated from leaves as per modified protocol of Mishra and Sabat (1995). The leaves were crushed in extraction buffer containing $300 \mathrm{mM}$ sucrose, $10 \mathrm{mM} \mathrm{NaCl}, 10 \mathrm{mM}$ $\mathrm{CaCl}_{2}, 5 \mathrm{mM} \mathrm{MgCl}_{2}, 10 \mathrm{mM}$ ascorbate and $20 \mathrm{mM}$ Tricine$\mathrm{NaOH}$ ( $\mathrm{pH}$ 7.5). The homogenate was filtered through four layers of muslin cloth and the filtrate centrifuged at $6000 g_{\mathrm{n}}$ for $5 \mathrm{~min}$. The pellet was suspended in $1 \mathrm{~mL}$ of suspension buffer containing $100 \mathrm{mM}$ sucrose, $10 \mathrm{mM}$ $\mathrm{NaCl}, 10 \mathrm{mM} \mathrm{CaCl}_{2}, 5 \mathrm{mM} \mathrm{MgCl}_{2}$ and $20 \mathrm{mM}$ Tricine- $\mathrm{NaOH}$ ( $\mathrm{pH}$ 7.5). The reaction mixture for assaying PSII activity consisted of 50 mM HEPES buffer ( $\mathrm{pH}$ 7.5) containing 400 $\mathrm{mM}$ sucrose, $5 \mathrm{mM} \mathrm{MgCl}$, and $10 \mathrm{mM} \mathrm{NaCl}$ in a final volume of $1 \mathrm{~mL}$. The activity was measured as oxygen evolution with water as electron donor and $500 \mu \mathrm{M}$ phenyl $p$-benzoquinone (pBQ) as the electron acceptor (Atal et al., 1991). For measurement of PSI-mediated electron transport, the reaction mixture consisted of assay buffer along with $5 \mu \mathrm{M}$ DCMU, $100 \mu \mathrm{M}$ dichlorophenol indophenol (DCPIP), $1 \mathrm{mM}$ ascorbate, 500 $\mu \mathrm{M}$ methyl viologen and $1 \mathrm{mM}$ sodium azide (Atal et al., 1991). The chlorophyll content in thylakoids was estimated according to Arnon (1949). The thylakoids equivalent to $10 \mu \mathrm{g}$ chlorophyll were used.

Fluorescence analysis: PSII efficiency was measured at room temperature using the Plant Efficiency Analyzer equipment (Handy PEA, Hansatech Instruments Ltd., Norfolk, England) with an excitation light intensity of $3000 \mu \mathrm{mol} \mathrm{m}^{-2} \mathrm{~s}^{-1}$ as per Appenroth et al. (2001). A single pulse of actinic light with a duration of $1 \mathrm{~s}$ was applied. All measurements were taken using 30 min dark-adapted intact leaves. The relative fluorescence values of initial $\left(\mathrm{F}_{0}\right)$, maximal $\left(\mathrm{F}_{\mathrm{m}}\right)$ and variable $\left(\mathrm{F}_{\mathrm{v}}\right)$ fluorescence were determined. The PSII efficiency was expressed as the $\mathrm{F}_{\mathrm{v}}$ '
$\mathrm{F}_{\mathrm{m}}$ ratio. The specific energy fluxes such as absorption (ABS), electron transport (ET) and dissipation (DI) per reaction center (RC) were also measured (Aragão et al., 2005).

Rubisco activity: The activity (Rubisco) (EC 4.1.1.39) was measured in a crude leaf extract following Sato et al. (1980). The assay reaction mixture consisted of $50 \mathrm{mM}$ Tris-HCl buffer ( $\mathrm{pH} 8.0$ ), $10 \mathrm{mM} \mathrm{NaHCO}_{3}, 5 \mathrm{mM} \mathrm{MgCl}_{2}, 2$ mM NADH, 1 mM ATP, 1 mM DTT, 0.5 mM RuBP, 5 U glyceraldehyde-3-phosphodehydrogenase, and $5 \mathrm{U}$ phosphoglycerate kinase in a final volume of $3 \mathrm{~mL}$. The change in absorbance was measured at $340 \mathrm{~nm}$.

Measurement of $\Delta p H$ : The formation of the transthylakoidal $\mathrm{pH}$ gradient $(\Delta \mathrm{pH})$ was measured in terms of quenching of the fluorescent dye 9aminoacridine. The reaction mixture consisted of $10 \mathrm{mM}$ Tricine-NaOH buffer ( $\mathrm{pH} 7.8$ ), $5 \mathrm{mM} \mathrm{NaCl}, 5 \mathrm{mM} \mathrm{MgCl}_{2}, 5$ $\mu \mathrm{M}$ dye and thylakoids equivalent to $10 \mu \mathrm{g}$ chlorophyll (Evron and McCarty, 2000). The fluorescence was measured using a microplate fluorescence reader (Flx-800, Biotek, Vermont, USA) at excitation and emission wavelengths of 360 and $430 \mathrm{~nm}$, respectively. Values of $\Delta \mathrm{pH}$ were calculated following Schludiner et al. (1972).

Photophosphorylation potential: The photophosphorylation reaction was measured in isolated thylakoids as per modified protocol of Lindon et al. (1993). The assay reaction mixture consisted of $25 \mathrm{mM}$ Tris buffer (pH 7.8), $20 \mathrm{mM} \mathrm{ADP,} 2 \mathrm{mM} \mathrm{KH}_{2} \mathrm{PO}_{4}, 1 \mathrm{mM}$ $\mathrm{K}_{3} \mathrm{Fe}(\mathrm{CN})_{6}$ and $5 \mathrm{mM}$ phenazine methosulfate (PMS). Thylakoids equivalent to $10 \mu \mathrm{g}$ chlorophyll were added. The reaction mixture was illuminated for 3 min using saturating white light at an intensity of $1000 \mu \mathrm{mol} \mathrm{m}^{-2} \mathrm{~s}^{-1}$. The concentration of ATP was determined enzymatically by reduction of NADP in presence of glucose, hexokinase and glucose-6-phosphate dehydrogenase (Lamprecht and Trautschold, 1976).

Measurement of pyridine nucleotides: $\mathrm{NADP}^{+}$and NADPH levels in isolated chloroplasts were measured according to enzyme cycling assay of Takahama et al. (1981). The reaction mixture consisted of $33 \mathrm{mM}$ Tris buffer (pH 7.6), 2 mM EDTA, 0.1 mM DCPIP, $60 \mu \mathrm{M}$ PMS, $3.3 \mathrm{mM}$ glucose 6 -phosphate and $10 \mu \mathrm{g}$ enzyme glucose- 
6-phosphate dehydrogenase. The reaction mixture was incubated for $5 \mathrm{~min}$. The reaction was started by adding enzyme and the change in the absorbance was followed at $600 \mathrm{~nm}$. The concentration of the pyridine nucleotides was determined according to standard curves prepared using known amounts of pyridine dinucleotides (Takahama et al., 1981).

From the measured concentrations of NADPH and NADP, the anabolic reduction charge (ARC) was calculated according to Backhausen et al. (2000):

$$
\mathrm{ARC}=[\mathrm{NADPH}] /\left[\mathrm{NADP}^{+}+\mathrm{NADPH}\right]
$$

Measurement of NADP-malate dehydrogenase (NADP$M D H$; EC 1.1.1.82) activity: The activity of enzyme was measured in isolated chloroplasts. The reaction mixture consisted of $100 \mathrm{mM}$ Tris-HCl (pH 8.0), 1 mM EDTA, 14 $\mathrm{mM} \beta$-mercaptoethanol, $2 \mathrm{mM}$ oxaloacetate and $0.2 \mathrm{mM}$ NADPH. The change in absorbance was measured at 340 $\mathrm{nm}$. The activity of enzyme measured immediately accounted for initial (non-activated) activity, while total activity was measured after complete activation of enzyme by incubating chloroplast suspension with 20 $\mathrm{mM}$ dithiothreitol at $\mathrm{pH} 8.0$ at room temperature. The final activity was expressed as the ratio of initial to total activity (activated) (Scheibe et al., 1986).

Data analysis: Analysis of variance (ANOVA) for all measured variables was performed using the software new MSTAT-C (version 2.1). The level of significance was measured using Duncan's multiple range test taking $P \leq 0.05$ as significant.

\section{RESULTS}

Heavy metal analysis: Various physico-chemical characteristics of wastewater samples were determined and their values are summarized in Table 1. Wastewater samples collected from an electroplating unit at different time intervals possessed $\mathrm{Cr}$ and $\mathrm{Zn}$ at the concentrations of 50 and $35 \mathrm{mg} \mathrm{L}^{-1}$, respectively. Chromium and $\mathrm{Zn}$ rich wastewater samples did not show the presence of heavy metals such as $\mathrm{Ni}, \mathrm{Pb}, \mathrm{As}, \mathrm{Co}$ but contained trace quantities of $\mathrm{Cu}, \mathrm{Cd}, \mathrm{Mn}, \mathrm{Zn}$ (Table 2). Salvinia accumulated $\mathrm{Cr}$ and $\mathrm{Zn}$ to levels as high as 10.6 and 4.8 $\mathrm{mg} \mathrm{g}^{-1} \mathrm{DW}$ on exposure to wastewaters having $50 \mathrm{mg} \mathrm{L}^{-1}$ $\mathrm{Cr}$ and $35 \mathrm{mg} \mathrm{L}^{-1}$ of $\mathrm{Zn}$, respectively (Figure 1).
Table 1. Physico-chemical characteristics of water, $\mathrm{Cr}$ and $\mathrm{Zn}$ wastewater samples measured at the time of experimental set up. EC = electrical conductivity; TDS = total dissolved solutes.

\begin{tabular}{lrrr}
\hline Parameters & Water & \multicolumn{1}{c}{$\mathrm{Cr}$} & $\mathrm{Zn}$ \\
\hline $\mathrm{pH}$ & 6.5 & 4.5 & 5.6 \\
\hline EC $(\mathrm{mS})$ & 0.51 & 0.82 & 0.93 \\
TDS $(\mathrm{ppt})$ & 0.53 & 0.52 & 0.83 \\
Chloride $\left(\mathrm{mg} \mathrm{L}^{-1}\right)$ & 91 & 87 & 107 \\
Sulphate $\left(\mathrm{mg} \mathrm{L}^{-1}\right)$ & 18 & 24 & 32 \\
Phosphate $\left(\mathrm{mg} \mathrm{L}^{-1}\right)$ & 9.8 & 8.5 & 11 \\
Nitrogen $\left(\mathrm{mg} \mathrm{L}^{-1}\right)($ Ammonical $)$ & 2.8 & 4.3 & 4.8 \\
Hardness $\left(\mathrm{mg} \mathrm{L}^{-1}\right)$ & 200 & 230 & 223 \\
\hline
\end{tabular}

Table 2. Heavy metal concentration of water, $\mathrm{Cr}$ and $\mathrm{Zn}$ wastewater samples measured at the time of experimental set up.

\begin{tabular}{lccr}
\hline Metals & \multicolumn{3}{c}{ Concentration $\left(\mathrm{mg} \mathrm{L}^{-1}\right)$} \\
\cline { 2 - 4 } & Water & $\mathrm{Cr}$ & $\mathrm{Zn}$ \\
\hline $\mathrm{Ni}$ & 0 & 0 & 0 \\
$\mathrm{~Pb}$ & 0 & 0 & 0 \\
$\mathrm{Co}$ & 0 & 0 & 0 \\
$\mathrm{As}$ & 0 & 0.12 & 0 \\
$\mathrm{Cd}$ & 0.09 & 0.9 & 0.12 \\
$\mathrm{Cu}$ & 0 & 0.8 & 0.95 \\
$\mathrm{Mn}$ & 0.2 & 50 & 1.8 \\
$\mathrm{Cr}$ & 0.5 & 1.8 & 0.3 \\
$\mathrm{Zn}$ & 1.5 & & 35 \\
\hline
\end{tabular}

Photosynthetic pigments: Accumulation of $\mathrm{Cr}$ and $\mathrm{Zn}$ at high levels induced decreases in concentrations of chlorophyll a, chlorophyll b and total chlorophylls, though the decline was more significant in $\mathrm{Zn}$-exposed plants (Table 3).

Photochemical activities: Primary photochemical activities measured polarographically using an oxygen electrode showed that PS-II-mediated photosynthetic electron transport was higher than the control in $\mathrm{Cr}$ exposed Salvinia but lower than the control in plants exposed to $\mathrm{Zn}$. The PS II activity of Cr-exposed plants showed a $\sim 1.6$ fold increase in comparison to the control. In contrast, a $\sim 25 \%$ reduction was noted in $\mathrm{Zn}$-exposed plants. The PS-I-mediated photochemical activity revealed $\mathrm{a} \sim 1.7$ and 2.6 fold increase in plants exposed to $\mathrm{Cr}$ and $\mathrm{Zn}$ rich wastewater, respectively (Figure 2). 

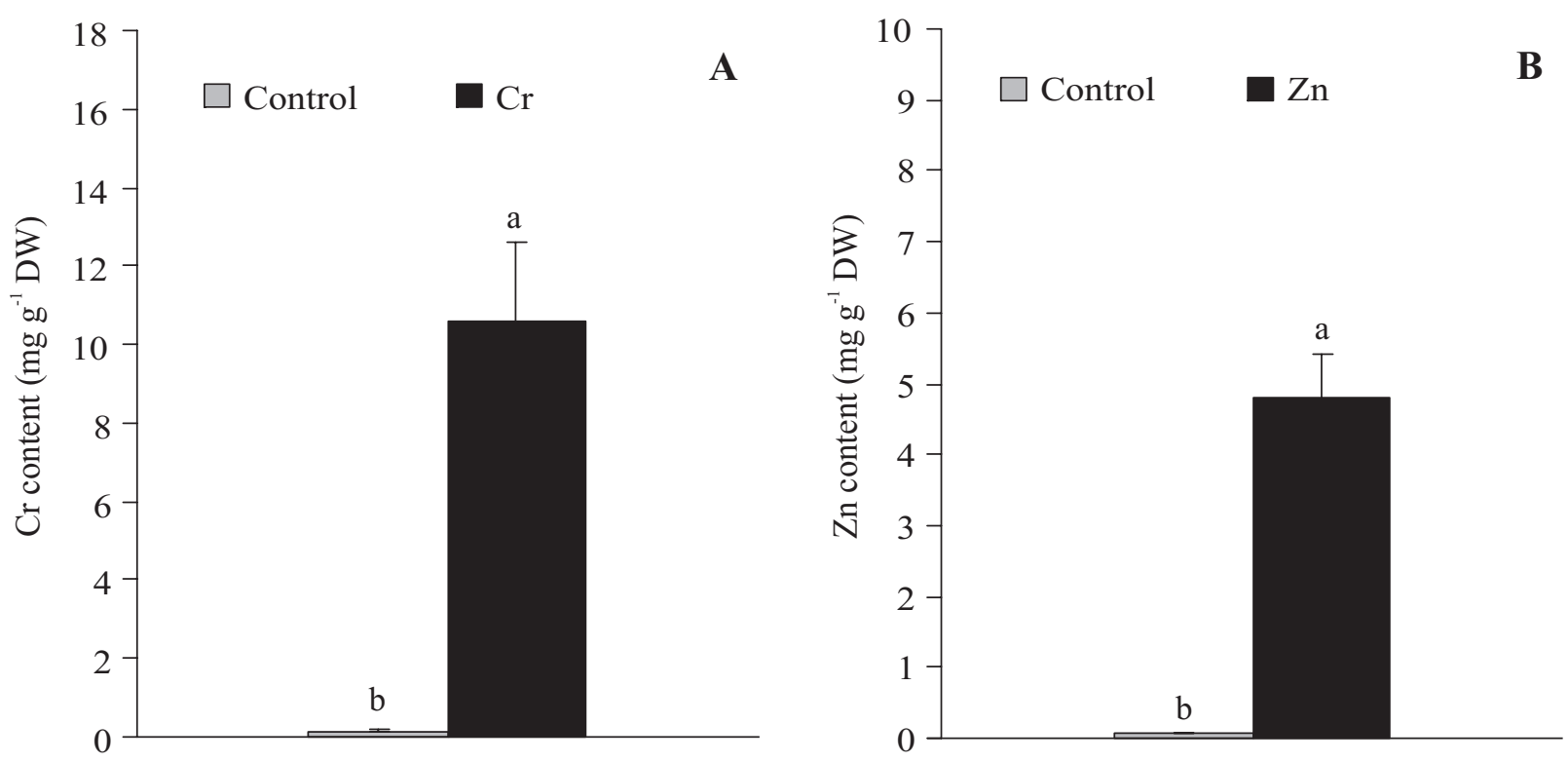

Figure 1. Chromium (A) and zinc (B) accumulation ( $\left.\mathrm{mg} \mathrm{g}^{-1} \mathrm{DW}\right)$ in Salvinia measured after $48 \mathrm{~h}$ of exposure to $\mathrm{Cr}$ and $\mathrm{Zn}$ rich wastewater. Each value represents the mean of five replicates \pm SE. The different letters over bars indicate significant differences at $P \leq 0.05$.

Table 3. Photosynthetic pigments $\left(\mathrm{mg} \mathrm{kg}^{-1} \mathrm{FW}\right)$ of Salvinia measured after $48 \mathrm{~h}$ of metal exposure. Each value represents the mean of five replicates \pm SE. Data followed by different letters in a column are significantly different at $P \leq 0.05$.

\begin{tabular}{lccc}
\hline \multicolumn{3}{c}{ Treatments } & Parameters \\
& Chlorophyll a & Chlorophyll b & Total chlorophyll \\
\hline Control & $458 \pm 47^{\mathrm{a}}$ & $149 \pm 16^{\mathrm{a}}$ & $616 \pm 64^{\mathrm{a}}$ \\
Cr & $427 \pm 44^{\mathrm{a}}$ & $141 \pm 16^{\mathrm{a}}$ & $574 \pm 55^{\mathrm{b}}$ \\
$\mathrm{Zn}$ & $409 \pm 43^{\mathrm{b}}$ & $129 \pm 14^{\mathrm{b}}$ & $550 \pm 56^{\mathrm{b}}$ \\
\hline
\end{tabular}

Fluorescence analysis: The fluorescence technique is used to assess photosynthetic performance of plants non-invasively based on its relationship with the quantum efficiency of electron transport through PS II in leaves Both the $\mathrm{F}_{0}$ and $\mathrm{F}_{\mathrm{m}}$ values showed a significant decline in both $\mathrm{Cr}$ - and $\mathrm{Zn}$-exposed plants. The $\mathrm{F}_{\mathrm{v}} / \mathrm{F}_{\mathrm{m}}$ ratio declined in $\mathrm{Zn}$-exposed plants in contrast to $\mathrm{Cr}$ exposed ones where the values remained more or less equal to the control (Table 4). Plants exposed to $\mathrm{Cr}$ presented a slight increase in absorption per reaction center without any significant alteration in electron transport. The reaction center molecules of $\mathrm{Cr}$-exposed plants utilized the absorbed light energy more efficiently, hence showing no significant alteration in electron transport. Accordingly, a low rate of energy dissipation was recorded. In contrast, damage to reaction center molecules in Zn-exposed plants adversely affected light absorption and hence utilization capacity, resulting in excessive energy dissipation (Table 4).

Rubisco activity: Activity of Rubisco, one of the major enzymes of the carbon fixation cycle, showed a significant decline of about $25 \%$ in $\mathrm{Cr}$ - and $\mathrm{Zn}$-exposed plants (Fig. 3).

Transthylakoidal $p H$ gradient ( $\Delta p H)$ and photophosphorylation potential: The increase in PS-Imediated electron flow observed in $\mathrm{Cr}$ - and $\mathrm{Zn}$-exposed plants contributed to a build up of $\Delta \mathrm{pH}$ in both $\mathrm{Cr}$ - and Zn-treated plants (Fig. 4A). On the other hand, the photophosphorylation potential did not show any significant change in plants exposed to $\mathrm{Cr}$ and $\mathrm{Zn}$ rich wastewater (Fig. 4B).

Pyridine nucleotides and NADP-malate dehydrogenase activity: Among the pyridine nucleotides, the levels of NADPH significantly increased in plants exposed to $\mathrm{Cr}$. In contrast, a significant decline was observed in $\mathrm{Zn}$ exposed plants (Table 5). Correspondingly, a considerable decline in $\mathrm{NADP}^{+}$levels was noted in plants 

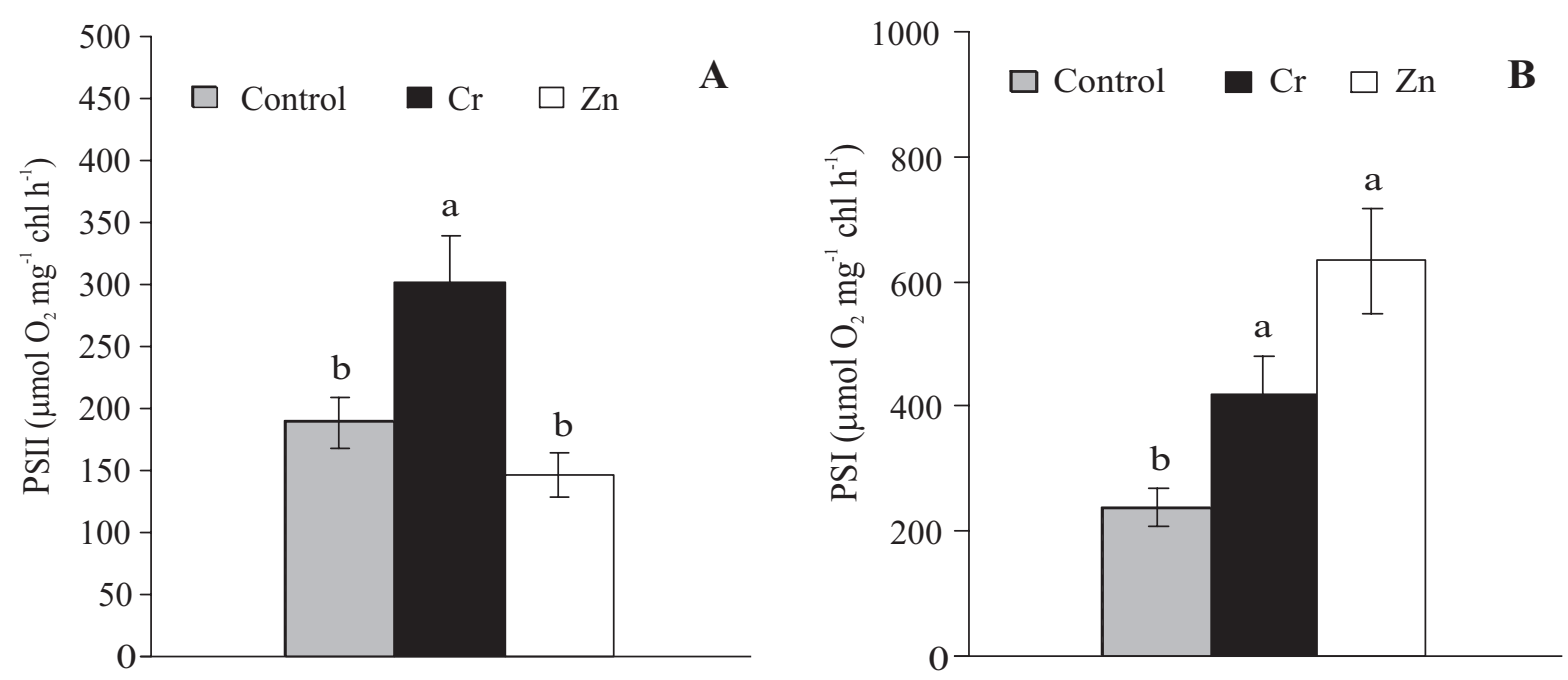

Figure 2. Alterations in PS II (A) and PS I (B) activity measured after $48 \mathrm{~h}$ of exposure to $\mathrm{Cr}$ and $\mathrm{Zn}$ rich wastewater. Statistics as in Figure 1.

Table 4. Changes in photosynthetic efficiency of plants measured through fluorescence after 48 h of metal exposure. The parameters measured include $\mathrm{F}_{0}$ (initial fluorescence), $\mathrm{F}_{\mathrm{m}}$ (maximum fluorescence), variable-to-maximum fluorescence ratio $\left(\mathrm{F}_{\mathrm{v}} / \mathrm{F}_{\mathrm{m}}\right)$, absorption per reaction center $(\mathrm{ABS} / \mathrm{RC})$, electron transport per reaction center $(\mathrm{ET} / \mathrm{RC})$, and dissipation per reaction center $(\mathrm{DI} / \mathrm{RC})$. All the values are expressed in relative units. Statistics as in Table 3.

\begin{tabular}{|c|c|c|c|c|c|c|}
\hline \multirow[t]{2}{*}{ Treatments } & \multicolumn{5}{|c|}{ Parameters } & \multirow[b]{2}{*}{$\mathrm{DI} / \mathrm{RC}$} \\
\hline & $\mathrm{F}_{0}$ & $\mathrm{~F}_{\mathrm{m}}$ & $\mathrm{F}_{\mathrm{v}} / \mathrm{F}_{\mathrm{m}}$ & $\mathrm{ABS} / \mathrm{RC}$ & $\mathrm{ET} / \mathrm{RC}$ & \\
\hline Control & $350 \pm 34^{\mathrm{a}}$ & $1650 \pm 178^{a}$ & $0.78 \pm 0.09^{a}$ & $4.66 \pm 0.56^{a}$ & $1.76 \pm 0.21^{\mathrm{a}}$ & $1.60 \pm 0.20^{\mathrm{a}}$ \\
\hline $\mathrm{Cr}$ & $303 \pm 32^{b}$ & $1215 \pm 119^{b}$ & $0.75 \pm 0.08^{\mathrm{a}}$ & $5.11 \pm 0.72^{b}$ & $1.48 \pm 0.50^{\mathrm{a}}$ & $1.38 \pm 0.24^{\mathrm{a}}$ \\
\hline $\mathrm{Zn}$ & $311 \pm 32^{\mathrm{b}}$ & $1009 \pm 120^{\mathrm{b}}$ & $0.69 \pm 0.07^{\mathrm{b}}$ & $2.57 \pm 0.3^{\mathrm{b}}$ & $1.53 \pm 0.17^{\mathrm{a}}$ & $2.49 \pm 0.34^{\mathrm{b}}$ \\
\hline
\end{tabular}

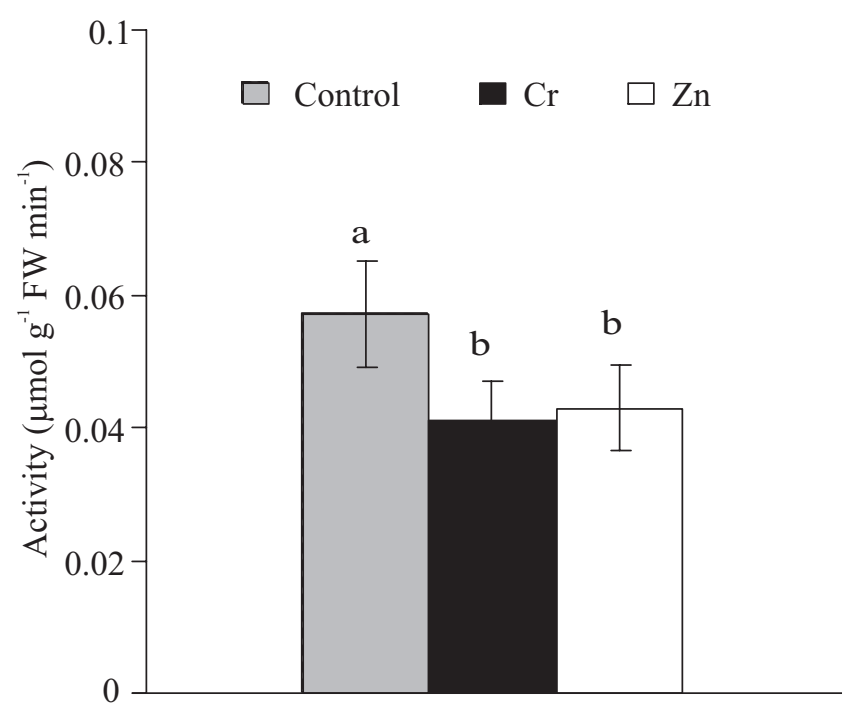

Figure 3. Rubisco activity of Salvinia measured after 48 $\mathrm{h}$ of exposure to $\mathrm{Cr}$ and $\mathrm{Zn}$ rich wastewater. Statistics as in Figure 1. exposed to $\mathrm{Cr}$ and $\mathrm{Zn}$. The anabolic reduction charge (ARC) ratio increased in plants exposed to $\mathrm{Cr}$ and $\mathrm{Zn}$ rich wastewater.

The NADP-MDH activity was enhanced in plants exposed to $\mathrm{Cr}$ and $\mathrm{Zn}$ rich wastewater (Table 5).

\section{DISCUSSION}

Salvinia exposed to $\mathrm{Cr}$ and $\mathrm{Zn}$ exhibited changes in photosynthetic potential. Alteration in levels of photosynthetic pigments affected the photosynthetic performance of Salvinia. The reduction in pigment levels in plants exposed to $\mathrm{Cr}$ and $\mathrm{Zn}$ rich wastewater could be the due to (i) reduced efficiency of enzymes involved in chlorophyll biosynthesis; (ii) decrease in availability of iron; and (iii) formation of metal substituted chlorophylls (Clijsters and Van Assche, 1985; Van Assche and Clijsters, 1990; Kupper et al., 1998). Similar responses of 

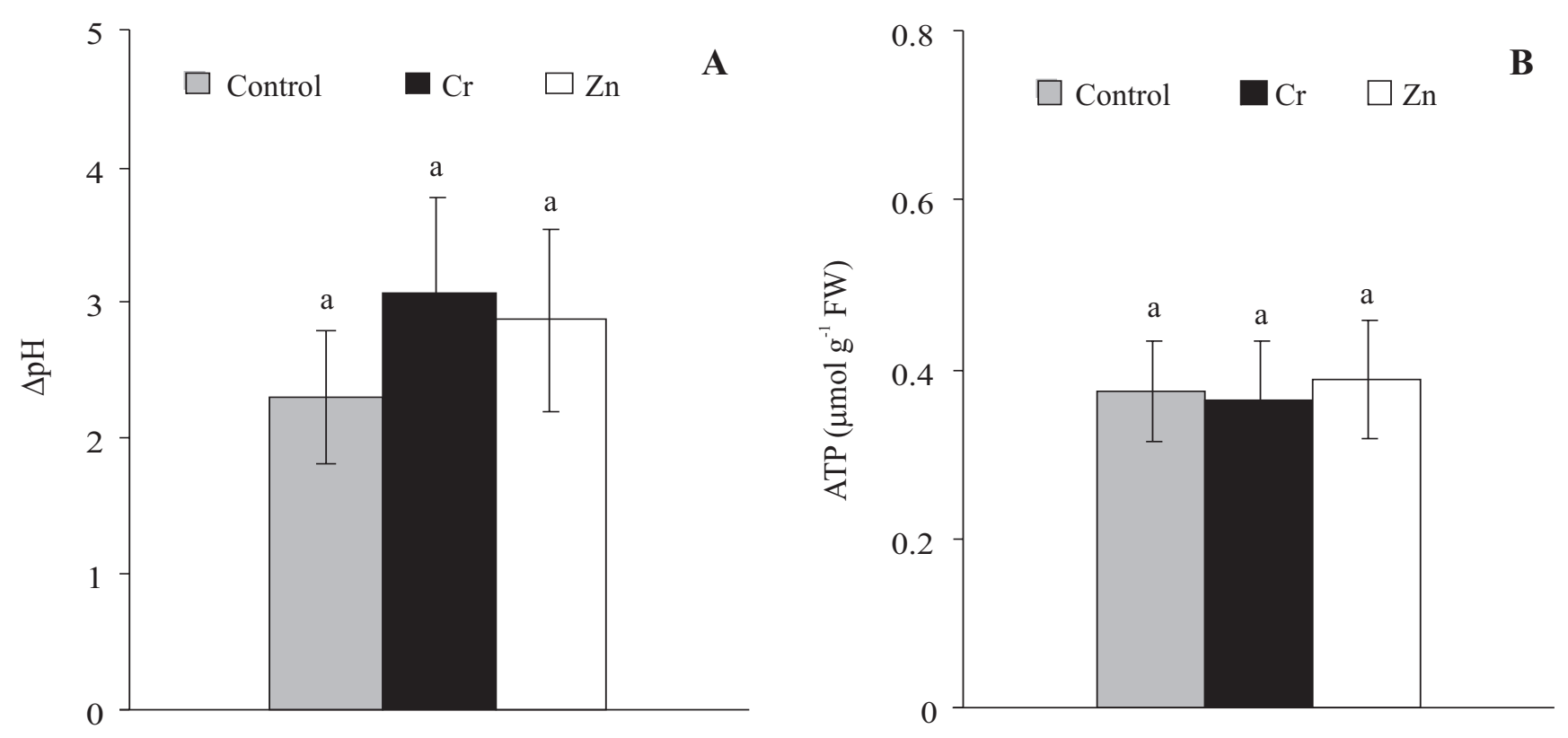

Figure 4. Changes in $\Delta \mathrm{pH}(\mathbf{A})$ and photophosphorylation potential (B) of Salvinia measured after $48 \mathrm{~h}$ exposure to $\mathrm{Cr}$ and $\mathrm{Zn}$ rich wastewater. Statistics as in Figure 1.

Table 5. Alterations in pyridine nucleotide levels $\left(\mathrm{NADP}^{+}, \mathrm{NADPH}\right)$, anabolic reduction charge (ARC), and NADPmalate dehydrogenase (NADP-MDH) activity measured after $48 \mathrm{~h}$ of metal exposure. Concentrations of NADP $^{+}$and NADPH levels expressed as nmol g-1 FW, and NADP-MDH activity is expressed as the ratio of activated and nonactivated enzyme activity. Statistics as in Table 3.

\begin{tabular}{|c|c|c|c|c|c|}
\hline \multirow[t]{2}{*}{ Treatments } & \multirow[b]{2}{*}{$\mathrm{NADP}^{+}$} & \multicolumn{3}{|c|}{ Parameters } & \multirow[b]{2}{*}{$\begin{array}{c}\text { NADP-MDH } \\
\text { activity } \\
\end{array}$} \\
\hline & & NADPH & $\begin{array}{l}\text { NADPH/ } \\
\text { NADP }^{+}\end{array}$ & ARC & \\
\hline Control & $9.8 \pm 1.2^{\mathrm{a}}$ & $5.17 \pm 0.61^{\mathrm{a}}$ & $0.53 \pm 0.07^{\mathrm{a}}$ & $0.34 \pm 0.04^{\mathrm{a}}$ & $1.48 \pm 0.17^{\mathrm{a}}$ \\
\hline $\mathrm{Cr}$ & $7.14 \pm 0.81^{b}$ & $7.77 \pm 0.91^{b}$ & $1.08 \pm 0.2^{\mathrm{b}}$ & $0.52 \pm 0.07^{\mathrm{b}}$ & $1.79 \pm 0.2^{\mathrm{a}}$ \\
\hline $\mathrm{Zn}$ & $5.9 \pm 0.7^{b}$ & $4 \pm 0.7^{\mathrm{b}}$ & $0.68 \pm 0.08^{\mathrm{a}}$ & $0.40 \pm 0.05^{\mathrm{a}}$ & $1.87 \pm 0.2^{\mathrm{a}}$ \\
\hline
\end{tabular}

reduction in photosynthetic pigments on exposure to heavy metals have been reported earlier in Salvinia species (Nichols et al., 2000; Al-Hamdani and Blair, 2004; Hadad et al., 2007). Among primary photochemical activities, PS-II-mediated electron transport remained more or less unaffected in plants exposed to $\mathrm{Cr}$ in contrast to that observed in $\mathrm{Zn}$-treated plants. The PS II photochemical efficiency, measured as $F_{v} / F_{m}$, showed no significant change in Cr-exposed plants. Accordingly, the absorption of light energy and electron transport per reaction center was equal to that of the control in $\mathrm{Cr}$ exposed plants. In contrast, Zn-treated plants showed a decline in $\mathrm{F}_{\mathrm{v}} / \mathrm{F}_{\mathrm{m}}$ in comparison to their respective controls. A Zn-induced decrease in light quenching capacity might have resulted from damage to reaction center molecules and/or loss in chlorophyll content (Chen et al., 2008). Moreover, reduced efficiency for utilization of light energy adversely affected electron transport, hence increasing energy dissipation.

In contrast, PS-I-mediated photoreactions measured polarographically exhibited an increase in plants exposed to $\mathrm{Cr}$ and $\mathrm{Zn}$ rich wastewaters. This could well be an acclimation response to cope with the additional flow of electrons during stress (Makino et al., 2002). In general, plants exposed to abiotic stresses reveal downregulation of linear electron flow and activation of cyclic electron transport, when linear electron flow becomes saturated (Fork and Herbert, 1993; Golding et al., 2004; 
Scheibe et al., 2005). The activation of PS I can also be linked to the decreased stromal $\mathrm{NADP}^{+} / \mathrm{NADPH}$ ratio (Rajagopal et al., 2003).

Salvinia exposed to $\mathrm{Cr}$ or $\mathrm{Zn}$ revealed a rise in $\Delta \mathrm{pH}$, which probably supported ATP synthesis under stress. It has been reported that enhancement in PS-I-mediated electron flow facilitates build up of the transthylakoidal proton gradient which acts as a driving force for ATP synthesis and helps in maintenance of photophosphorylation potential under stress (Backhausen et al., 2000; Makino et al., 2002). Moreover, the heavy metal-induced decrease in functioning of Calvin cycle enzymes also results in accumulation of ATP and NADPH leading to feedback inhibition of electron transport and increase in the transthylakoidal proton gradient (Siedlecka et al., 1997; Romanwoska et al., 2002; Siedlecka and Krupa, 2004). Adequate amounts of reducing equivalents such as NADPH and NADH are required for maintenance of stromal redox status (Backhausen et al., 2000). In this context, the increase in $\mathrm{NADPH} / \mathrm{NADP}^{+}$ratio of $\mathrm{Cr}$-exposed plants could be the consequence of either reduced utilization of NADPH resulting from a decline in Rubisco activity (thus preventing oxidation of stroma) or enhanced synthesis resulting from cyclic electron flow around PS I to meet the additional requirements of reducing equivalents during $\mathrm{CO}_{2}$ fixation (Backhausen et al., 2000). Heavy metalinduced increases in NADPH levels have also been reported in aquatic plant species such as Phragmites australis (Pietrini et al., 2003). Alterations in NADPH levels have been reported in plants exposed to heat, chilling and other abiotic stresses (Schrader et al., 2004, 2007). In any case, since the ARC values were high in plants exposed to $\mathrm{Cr}$ and $\mathrm{Zn}$ rich wastewater, a low demand for NADPH in the stroma is to be expected. Similar responses of increase in redox status (NADPH/ $\mathrm{NADP}^{+}$) and phosphorylation potential of Scots pine seedlings exposed to high concentrations of metals such as $\mathrm{Al}(4 \mathrm{mM})$ have also been reported (Plucinska and Karolewski, 1994). The carbon fixation/assimilation potential was severely affected in plants exposed to $\mathrm{Cr}$ or $\mathrm{Zn}$ as evident from the decline in Rubisco activity. The deactivation of the enzyme after substitution of $\mathrm{Mg}^{2+}$ in the ternary Rubisco complex by metal cations can result in loss of carboxylation capacity (Van Assche and Clijsters, 1990). The decrease in $\mathrm{CO}_{2}$ assimilation capacity of Salvinia has also been correlated with a decrease in photosynthetic pigments (Nichols et al., 2000; A1Hamdani and Blair, 2004). Similar responses of decline in Rubisco activity have also been reported previously for a few aquatic species (Pietrini et al., 2003).

During photosynthesis, plants develop certain strategies to maintain homeostasis under stress. These mainly include activation of some thiol regulated chloroplast enzymes including NADP-MDH, the activation of which has been used as an indicator of redox state of stroma (Scheibe and Stitt, 1988). The enzyme catalyzes the formation of malate from oxaloacetate using NADPH to generate an electron acceptor, i.e. $\mathrm{NADP}^{+}$, and its activity is switched off when NADPH is consumed by assimilatory processes in the chloroplast so that no reducing equivalents are exported (Scheibe et al., 2005). It is supposed that activation of the enzyme provides a way for reducing equivalents to allow some electron transport and proton pumping. Salvinia exposed to $\mathrm{Cr}$ and $\mathrm{Zn}$ did not exhibit a significant increase in NADP-MDH activity indicating that metal stress does not affect stromal status as adequate levels of NADPH and other reducing equivalents are maintained for $\mathrm{CO}_{2}$ assimilation. It is supposed that closure of the malate valve under stress also prevents drainage of excess reducing equivalents from the chloroplast, hence preventing the oxidation of stroma (Scheibe and Stitt, 1988; Schrader et al., 2004). The effect of ARC and redox state on the enzyme activation has also been reported (Backhausen et al., 2000).

Conclusively, the present investigations revealed that changes in the photosynthetic potential of S. natans, irrespective of exposure to heavy metals $\mathrm{Cr}$ or $\mathrm{Zn}$, could be primarily the result of alterations in photosynthetic electron transport or carbon assimilation without significant effects on photophosphorylation potential. The studies also suggest that $\mathrm{CO}_{2}$ assimilation reactions are more sensitive to $\mathrm{Cr}$ exposure than photosynthetic electron transport and ATP-producing reactions, while in the case of exposure to $\mathrm{Zn}$ both $\mathrm{CO}_{2}$ assimilation potential and photosynthetic electron transport are equally sensitive.

Acknowledgments: The financial support from the Department of Science and Technology, New Delhi to Bhupinder Dhir is gratefully acknowledged. 


\section{REFERENCES}

Al-Hamdani SH, Blair SL (2004) Influence of copper on selected physiological responses in Salvinia minima and its potential use in copper remediation. Am. Fern J. 94:47-56.

APHA (1998) Standards Methods for Examination of Water and Wastewater. $20^{\text {th }}$ ed, American Public Health Association, Washington DC.

Appenroth KJ, Stöckel J, Srivastava A, Strasser RJ (2001) Multiple effects of chromate on the photosynthetic apparatus of Spirodela polyrhiza as probed by OJIP chlorophyll $a$ fluorescence measurements. Environ. Pollut. 115: 49-64.

Aragão MEF, Guedes MM, Otoch MO, Guedes MIF, de Melo DF, Lima MGS (2005) Differential responses of RuBP carboxylase/oxygenase activities of two Vigna unguiculata cultivars to salt stress. Braz. J. Plant Physiol. 17:207-212.

Arnon DI (1949) Copper enzymes in isolated chloroplasts. Polyphenol oxidase in Beta vulgaris. Plant Physiol. 24:1-15.

Atal N, Saradhi PP, Mohanty P (1991) Inhibition of chloroplast photochemical reactions by treatment of wheat seedlings with low concentrations of cadmium: analysis of electron transport activities and changes in the fluorescence yield. Plant Cell Physiol. 32: 943-951.

Backhausen JE, Kitzmann C, Horton P, Scheibe R (2000) Electron acceptors in isolated intact chloroplasts act hierarchically to prevent over reduction and competition for electrons. Photosynth. Res. 64:1-13.

Chen W, Yang X, He Z, Feng Y, Hu F (2008) Differential changes in photosynthetic capacity, $77 \mathrm{~K}$ chlorophyll fluorescence and chloroplast ultrastructure between $\mathrm{Zn}$-efficient and $\mathrm{Zn}$-inefficient rice genotypes (Oryza sativa) under low zinc stress. Physiol. Plant. 132:89101.

Clijsters H, Van Assche F (1985) Inhibition of photosynthesis by heavy metals. Photosynth. Res. 7:31-40.

Dushenkov V, Kumar PBAN, Motto H, Raskin I (1995) Rhizofiltration: The use of aquatic plants to remove heavy metals from wastewater streams. Environ. Sci. Technol. 29:1239-1245.

Evron Y, McCarty RE (2000) Simultaneous measurement of $\Delta \mathrm{pH}$ and electron transport in chloroplast thylakoids by 9 aminoacridine fluorescence. Plant Physiol. 124:407-414.

Fork D, Herbert SK (1993) Electron transport and photophosphorylation by photosystem I in vivo in plant cyanobacteria. Photosynth. Res. 36:149-168.

Golding AJ, Finazzini G, Johnson GN (2004) Reduction of thylakoid electron transport by stromal reductants: evidence for activation of cyclic electron transport upon dark adaptation or under drought. Planta 220:356-363.

Hadad HR, Maine MA, Natale GS, Bonetto C (2007) The effect of nutrient addition on metal tolerance in Salvinia herzogii. Ecol. Eng. 31:122-131.

Hoffman T, Kutter C, Santamaria J (2004) Capacity of Salvinia minima Baker to tolerate and accumulate As and $\mathrm{Pb}$. Eng. Life Sci. 4:61-65.

Kara Y (2005) Bioaccumulation of $\mathrm{Cu}, \mathrm{Zn}$ and $\mathrm{Ni}$ from the wastewater by treated Nasturtium officinale. Int. J. Environ. Sci. Technol. 2:63-67.

Krupa Z, Baszynski T (1995) Some aspects of heavy metal toxicity towards photosynthetic apparatus - Direct and indirect effects on light and dark reactions. Acta Physiol. Plant. 17:177-190.

Kupper H, Kupper F, Miller S (1998) In situ detection of heavy metal substituted chlorophyll in water plants. Photosynth. Res. 58:123-133.

Lamprecht W, Trautschold I (1976) Determination with hexokinase and glucose-6-phosphate dehydrogenase. In: Bergmeyer HU (ed), Methods in Enzymatic Analysis, pp.2101-2110. Academic Press Inc., New York.

Lindon FC, Ramalho JC, Henriques FS (1993) Copper inhibition of rice photosynthesis. J. Plant Physiol. 142: 12-17.

Makino A, Miyake C, Yokota A (2002) Physiological functions of water-water cycle (Mehler reaction) and cyclic electron flow around PS I in rice leaves. Plant Cell Physiol. 43:1017-1026.

Mishra SR, Sabat SC (1995) Effect of calcium ion on Hydrilla verticillata thylakoid membrane oxygen evolution. Indian J. Biochem. Biophys. 32: 94-99.

Nichols PB, Couch JD, Al Hamdani SH (2000) Selected physiological responses of Salvinia minima to different concentrations of chromium. Aquat. Bot. 68:313-319.

Nigam KDP, Srivastav, RK, Gupta, SK, Vasudevan P (1998) A mathematical model for metal ion uptake by 
aquatic plants from wastewater treatment. Environ. Assess. Model. 3:249-258.

Panda SK, Choudhury S (2005) Chromium stress in plants. Braz. J. Plant Physiol. 17:95-102.

Pietrini F, Iannelli MA, Pasqualini S, Massacci A (2003) Interaction of cadmium with glutathione and photosynthesis in developing leaves and chloroplasts of Phragmites australis (Cav.) Trin. ex Steudel. Plant Physiol.133 829-837.

Plucinska GL, Karolewski P (1994) Aluminium effects on pyridine nucleotide redox state in roots of Scots pine. Acta Soc. Bot. Pol. 63:167-171.

Rai UN, Tripathi RD, Vajpayee P, Pandey N, Ali MB, Gupta DK (2003) Cadmium accumulation and is phytotoxicity in Potamogeton pectinatus L. (Potamogetonaceae). Bull. Environ. Contam. Toxicol. 70:566-575.

Rajagopal S, Bukhov NG, Tajmoir-Riahi H, Carpentier R (2003) Control of energy dissipation and photochemical activity in photosystem I by NADP dependent reversible conformational changes. Biochemistry 42:11839-11845.

Romanowska E, Igamberdieva AU, Parysa E, Gardeström $\mathrm{P}$ (2002) Stimulation of respiration by $\mathrm{Pb}^{2+}$ in detached leaves and mitochondria of $\mathrm{C} 3$ and $\mathrm{C} 4$ plants. Physiol. Plant. 116:148-154.

Rout GR, Das P (2003) Effect of heavy metal toxicity on plant growth and metabolism. I Zinc. Agronomie 23:3-11.

Sato FK, Nishida K, Yamada Y (1980) Activities of carboxylation enzymes and products of ${ }^{14} \mathrm{CO}_{2}$ fixation in photoautotrophically cultured cells. Plant Sci. Lett. 20:91-97.

Scheibe R, Stitt M (1988) Comparison of NADP-malate dehydrogenase activation, $\mathrm{Q}_{\mathrm{A}}$ reduction and $\mathrm{O}_{2}$ evolution in spinach leaves. Plant Physiol. Biochem. 26:473-481.

Scheibe R, Wagenpfeil D, Fischer J (1986) NADP-malate dehydrogenase activity during photosynthesis in illuminated spinach chloroplasts. J. Plant Physiol. 124:103-110.

Scheibe R, Backhausen JE, Emmerlich U, Holtgrefe S (2005) Strategies to maintain the redox homeostasis during photosynthesis under changing conditions. J. Exp. Bot. 56:1481-1489.

Schrader SM, Wise RR, Wacholtz WE, Sharkey TD (2004) Thylakoid membrane responses to moderately high leaf temperature temperature in Pima cotton. Plant Cell Environ. 27:725-735.

Schrader SM, Kleinbeck KR, Sharkey TD (2007) Rapid heating of intact leaves reveals initial effects of stromal oxidation on photosynthesis. Plant Cell Environ. 30:671-678.

Schuldiner S, Rottenberg H, Avron M (1972) Determination of $\Delta \mathrm{pH}$ in chloroplasts. 2. Fluorescent amines as a probe for determination of $\Delta \mathrm{pH}$ in chloroplasts. Eur. J. Biochem. 25:64-70.

Sen AK, Mondal NG (1990) Removal and uptake of Cu (II) by Salvinia natans from wastewater. Water Air Soil Pollut. 49:1-6.

Sen AK, Bhattacharya M (1994) Studies of uptake and toxic effects of Ni on Salvinia natans. Water Air Soil Pollut. 78:141-152.

Sersen F, Kralova K, Bumbalova A (1998) Action of mercury on the photosynthetic apparatus of spinach chloroplasts. Photosynthetica 35:551-559.

Shanker AK, Cervantes C, Loza-Tavera H, Avudainayagam S (2005) Chromium toxicity in plants. Environ. Int. 31:739-753.

Sharma, P Dubey, RS (2005) Lead toxicity in plants. Braz. J. Plant Physiol.17:35-52.

Siedlecka A, Krupa Z (2004) Rubisco activity maintenance in environmental stress conditions: How many strategies? Cell Mol. Biol. Lett. 9:56-57.

Siedlecka A, Gardestrom P, Samuelson G, Oquist G, Gardestrom P (1997) Primary carbon metabolism in Phaseolus vulgaris plants under $\mathrm{Cd} / \mathrm{Fe}$ interaction. Plant Physiol. Biochem. 35:951-957.

Takahama U, Shimizu-Takahama M, Heber U (1981) The redox state of the NADP system in illuminated chloroplasts. Biochim. Biophys. Acta 637:530-539.

Van Assche F, Clijsters H (1990) Effects of metals on enzyme activity in plants. Plant Cell Environ. 13:195206. 